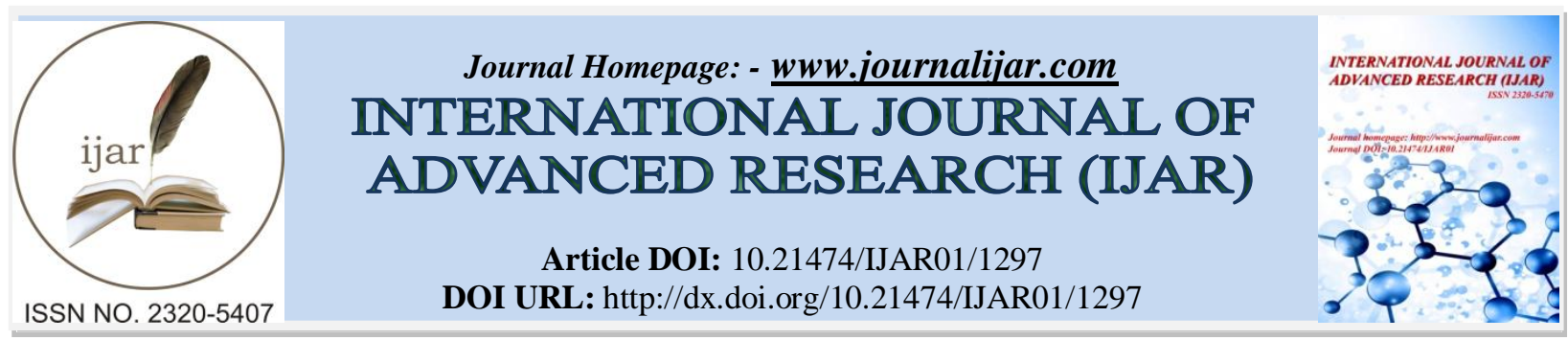

RESEARCH ARTICLE

\title{
EXPLORING THE KEY FACTORS OF PHYSICAL STRESS AMONG UNORGANIZED WORKERS EMPIRICAL EVIDENCE FROM LUCKNOW, UTTAR PRADESH.
}

\author{
Kalpana devi ${ }^{1}$ and U. V. Kiran ${ }^{2}$. \\ 1. Research Scholar Department of Human Development and Family Studies, School for Home Sciences. \\ Babasaheb Bhimrao Ambedker University, Lucknow. \\ 2. Assistant Professor Department of Human Development and Family Studies, School for Home Sciences. \\ Babasaheb Bhimrao Ambedker University, Lucknow.
}

\section{Manuscript Info}

Manuscript History

Received: 18 June 2016

Final Accepted: 19 July 2016

Published: August 2016

Key words:-

Occupational stress, Physical stress,

Unorganised sector, Working conditions.

\section{Abstract}

Unorganized sector is the largest sector with high employment opportunity. There were several types of jobs to the individuals according to their skills. In present global, fast dynamic environment, demand of higher productivity with economic cost has been increased, which forces the workers to put extra effort in the job. The working conditions of unorganised sector declines and the workers have to suffer the consequences in the form of stress. The present research tried to explore among the workers of five sectors construction labor, chikankari workers, Brick kiln worker, sanitary and ornamental worker, the identification of key factors which has major role in the measurement of the physical stress. A sample of five hundred respondents compressing 100 each from each sector, was selected for conducting the present study. Modified version of Occupational Stress Scale was used to assess the physical stress through principal component analysis. The study conclude that the physical stress was mainly due to five different factors physical exertion, lack of enough time for family, prone to injuries, uncomfortable due to seasonal changes and working tools. In order to improve the level of productivity, the employer of these sectors has to enhance the level of intervention in relation to the safety at work place, ergonomically designed tools, health care facility for the workers at their work places.

Copy Right, IJAR, 2016,. All rights reserved.

\section{Introduction:-}

In this fast dynamic global environment, the speed of human life also has become fast; they have to face the competition of high intensity at different places for the survival. In present globalised economy, the worker have to work for the longer time period and in different working conditions due to pressure of increased productivity. This working condition contributes to increase in the perceived level of stress, which influences the workers productivity and well being. The physical stress can be understood through different components. The major influencing factor of the physical stress is stress due to job, Body discomfort, leading to musculoskeletal disorders in long time.

\section{Corresponding Author:- Kalpana devi}

Address:- Research Scholar Department of Human Development and Family Studies, School for Home 1001

Sciences. Babasaheb Bhimrao Ambedker University, Lucknow. 
"Predominance of informal employment has been one of the central features of the labour market scenario in India. While the sector contributes around half of the GDP of the county, its dominance in the employment front is such that more than $90 \%$ of the total workforce has been engaged in the informal economy. As per the latest estimation of a Sub-committee of the National Commission for Enterprises in the Unorganized Sector (NCEUS), the contribution of unorganized sector to GDP is about 50\%" (NCEUS 2008).

The construction workers, handloom workers, sanitary workers, brick kiln industry were the major sectors where the demand of employment is very high. Construction industry provides job opportunity to large number of skilled as well as unskilled workforce. The workforce employed in the industry have to work for long working hours, different working conditions at the work place and the workers have several issues related to health, job stress, and injuries at work place (Devi \& Kiran, 2013). Most of the workers of construction were migrant workers and are provoked by lack of opportunities at home as well as at work places. Indian unorganized sector produces over 340 million workers contributing to $60 \%$ of national economic output (Mohanaraj \& Manivannan, 2013).

There were several other jobs offered by the unorganized sector, along with job opportunity, it also offers flexibility of working places as it will be the fruitful to the workers but on the same time it threatens the workers in terms of negotiation in income, which leads to the harassment and decline in the value of skills. The workers, who work through their homes sacrifices the proper valuation of their skills, and face the problems related to adjustment between work and housework, on the other side the workers who work outside have to face the adjustment problems related to the fooding, lodging and health. The major fact is that workers have to work several hours in different body posture, dealings, with different kinds of materials and tools, which may be dangerous to the health, along with the materials and tools the working environment also puts pressure to the workers, which results in form of physical discomfort such as high risk of musculoskeletal disorders, stress, depression, anxiety and some time behavioral changes.

\section{Objective:-}

The present study has been conducted for the purpose of identification and analysis of the important key factors responsible for the physical stress among the selected construction, brick kilns, chikankari, ornamental, sanitary, workers, along with this, the present study tried to explore the level of understanding about the measurement of the physical stress.

\section{Materials and methods:-}

The present study was carried out among the worker's working in unorganized sectors at Lucknow city, India. Unorganized sector for the present study comprised of construction, chikankari, brick kilns, sanitary and ornamental workers. The physical stress was assessed using modified version of occupational stress scale developed by Srivastava, A.K. (1976) along with self made statements based on the identified sources of stress from the literature. Using interview schedule, 500 workers comprising of 100 per sector was selected for the present study. In order to identify the underlying sub dimension of the construct, physical stress, Principal component factor analysis has been performed.

\section{Results:-}

Factor Analysis has been performed for the extraction of sub dimension of physical stress. The respondents were asked to give their responses for the different statements. Output of the factor analysis was as below.

\section{Correlation Analysis}

The upper part of the table shows the correlation coefficients and lower part of the table depicts the significance, the significance value for each variables was checked and maximum values for any variables are greater than 0.05 , and then scanned the correlation value, which were not as much higher as 0.90 for all the variables. after scanning the table it is observed that there is no variables for which maximum significant correlation values is greater than 0.05 , then check that no variables have correlations value higher as 0.9 . The detriment value of the table 0.001 is much greater than 0.000001 , which indicate that the multi co linearity among the variable were minimum and we do not have to drop any of the variables. 
Table 1:- KMO and Bartlett's Test.

\begin{tabular}{|c|c|c|}
\hline \multicolumn{3}{|l|}{ KMO and Bartlett's Test } \\
\hline \multicolumn{2}{|c|}{ Kaiser-Meyer-Olkin Measure of Sampling Adequacy. } & .773 \\
\hline \multirow[t]{3}{*}{ Bartlett's Test of Sphericity } & Approx. Chi-Square & 3301.759 \\
\hline & $\mathrm{df}$ & 136 \\
\hline & Sig. & 0.000 \\
\hline
\end{tabular}

The value of Kaiser-Meyer-Olkin Measure of Sampling Adequacy, of this statistics lies between 0 and 1 . The zero value indicate that sum of square of the partial correlation is higher, which were not appropriate for the factor analysis, whereas the value of this statistics intend towards one and which indicates that it is appropriate for applying the factor analysis. The above table shows 0.773 value for KMO test, which is good enough. Bartlett's Test of Sphericity, test the null hypothesis that the correlation matrix is an identity matrix, that means all the variables do not have any significant correlations and for the factor analysis we require certain correlation, the value of significant, 0.000 for the present research clearly indicates that factor analysis can be appropriately adopted to several underlying vital dimensions.

Table 2:- Total Variance Explained.

\begin{tabular}{|c|c|c|c|c|c|c|c|c|c|}
\hline \multirow[t]{2}{*}{$\begin{array}{l}\text { Compone } \\
\mathrm{nt}\end{array}$} & \multicolumn{3}{|c|}{ Initial Eigen values } & \multicolumn{3}{|c|}{$\begin{array}{l}\text { Extraction Sums of Squared } \\
\text { Loadings }\end{array}$} & \multicolumn{3}{|c|}{$\begin{array}{l}\text { Rotation Sums of Squared } \\
\text { Loadings }\end{array}$} \\
\hline & $\begin{array}{l}\text { Tota } \\
1\end{array}$ & $\begin{array}{l}\% \text { of } \\
\text { Varianc } \\
\mathrm{e}\end{array}$ & $\begin{array}{l}\text { Cumulativ } \\
\text { e } \%\end{array}$ & $\begin{array}{l}\text { Tota } \\
1\end{array}$ & $\begin{array}{l}\% \text { of } \\
\text { Varianc } \\
\mathrm{e}\end{array}$ & $\begin{array}{l}\text { Cumulativ } \\
\text { e } \%\end{array}$ & Total & $\begin{array}{l}\% \text { of } \\
\text { Varianc } \\
\mathrm{e}\end{array}$ & $\begin{array}{l}\text { Cumulativ } \\
\text { e } \%\end{array}$ \\
\hline 1 & $\begin{array}{l}4.51 \\
8\end{array}$ & 26.579 & 26.579 & $\begin{array}{l}4.51 \\
8\end{array}$ & 26.579 & 26.579 & $\begin{array}{l}3.63 \\
2\end{array}$ & 21.365 & 21.365 \\
\hline 2 & $\begin{array}{l}2.58 \\
3\end{array}$ & 15.196 & 41.775 & $\begin{array}{l}2.58 \\
3\end{array}$ & 15.196 & 41.775 & $\begin{array}{l}2.19 \\
5\end{array}$ & 12.913 & 34.277 \\
\hline 3 & $\begin{array}{l}1.51 \\
4\end{array}$ & 8.907 & 50.682 & $\begin{array}{l}1.51 \\
4\end{array}$ & 8.907 & 50.682 & $\begin{array}{l}1.97 \\
5\end{array}$ & 11.616 & 45.894 \\
\hline 4 & $\begin{array}{l}1.26 \\
5\end{array}$ & 7.440 & 58.123 & $\begin{array}{l}1.26 \\
5\end{array}$ & 7.440 & 58.123 & $\begin{array}{l}1.76 \\
5\end{array}$ & 10.385 & 56.279 \\
\hline 5 & $\begin{array}{l}1.13 \\
0\end{array}$ & 6.646 & 64.769 & $\begin{array}{l}1.13 \\
0\end{array}$ & 6.646 & 64.769 & $\begin{array}{l}1.44 \\
3\end{array}$ & 8.490 & 64.769 \\
\hline 6 & .875 & 5.147 & 69.916 & & & & & & \\
\hline 7 & .795 & 4.675 & 74.591 & & & & & & \\
\hline 8 & .704 & 4.143 & 78.733 & & & & & & \\
\hline 9 & .698 & 4.103 & 82.836 & & & & & & \\
\hline 10 & .559 & 3.287 & 86.123 & & & & & & \\
\hline 11 & .467 & 2.749 & 88.872 & & & & & & \\
\hline 12 & .449 & 2.641 & 91.513 & & & & & & \\
\hline 13 & .414 & 2.436 & 93.948 & & & & & & \\
\hline 14 & .357 & 2.102 & 96.051 & & & & & & \\
\hline 15 & .332 & 1.951 & 98.002 & & & & & & \\
\hline 16 & .234 & 1.378 & 99.380 & & & & & & \\
\hline 17 & .105 & .620 & 100.000 & & & & & & \\
\hline $\begin{array}{l}\text { Extractio } \\
\text { Analysis. }\end{array}$ & Methor & Principal & Component & & & & & & \\
\hline
\end{tabular}

Five components were extracted through factor extraction, and the cumulative explained variance is $64.7 \%$. The first component have highest variance explanation (26\%) power, the rotated sums of squared loading table showed that the variances explained by the extraction factors. 
Table 3:- Communality Table.

\begin{tabular}{|c|c|c|c|c|c|}
\hline Statement & initial & extracted & statement & initial & extracted \\
\hline $\begin{array}{l}\text { I get less salary in } \\
\text { comparison the quantum } \\
\text { of my labour }\end{array}$ & 1.000 & .641 & $\begin{array}{l}\text { Summer season is not comfortable } \\
\text { due to work }\end{array}$ & 1.000 & .752 \\
\hline $\begin{array}{l}\text { I have to do lot of work } \\
\text { when compared to other } \\
\text { workers }\end{array}$ & 1.000 & .674 & $\begin{array}{l}\text { Rainy season is not comfort able for } \\
\text { occupation }\end{array}$ & 1.000 & .767 \\
\hline $\begin{array}{l}\text { I am not able to follow a } \\
\text { regular meal pattern }\end{array}$ & 1.000 & .839 & $\begin{array}{l}\text { Feel uncomfortable due to coarse and } \\
\text { hard material of handles of various }\end{array}$ & 1.000 & .612 \\
\hline $\begin{array}{l}\text { I am not able to give } \\
\text { sufficient time for } \\
\text { cooking and feeding my } \\
\text { family }\end{array}$ & 1.000 & .836 & $\begin{array}{l}\text { Skin and nails remain hard and } \\
\text { unsmoth during working period }\end{array}$ & 1.000 & .610 \\
\hline $\begin{array}{l}\text { Suffer from heavy } \\
\text { palpitation of my heart } \\
\text { while performing the } \\
\text { activity }\end{array}$ & 1.000 & .500 & $\begin{array}{l}\text { Physically fatigued or exhausted } \\
\text { while performing the activity due to } \\
\text { occupation }\end{array}$ & 1.000 & .391 \\
\hline $\begin{array}{l}\text { Suffer from asthma due } \\
\text { to occupation }\end{array}$ & 1.000 & .583 & I sweat or feel thirsty while working & 1.000 & .580 \\
\hline $\begin{array}{l}\text { Feel irritation and } \\
\text { redness is the eyes } \\
\text { during working period }\end{array}$ & 1.000 & .700 & $\begin{array}{l}\text { Get injured due to stones sticks } \\
\text { during working period }\end{array}$ & 1.000 & .561 \\
\hline \begin{tabular}{llr} 
Gets nose & \multicolumn{2}{c}{ irritation } \\
sneezing and feel \\
suffocated when dust \\
enters in nose
\end{tabular} & 1.000 & .674 & $\begin{array}{l}\text { Get injured due to stones sticks } \\
\text { during working period }\end{array}$ & 1.000 & .561 \\
\hline $\begin{array}{l}\text { Suffer from allergies due } \\
\text { to material used in work }\end{array}$ & 1.000 & .641 & & & \\
\hline $\begin{array}{l}\text { Feel dizziness and } \\
\text { nausea due to fumes of } \\
\text { chemicals used in } \\
\text { working period }\end{array}$ & 1.000 & .650 & & & \\
\hline
\end{tabular}

The communality table shows that the portion of common variance shared by a factor. Initially all the factors with values 1. were considered After extraction, it is extracted values which reflect the common variances by the factors, from the table it was observed that the third statements were having the highest sharing variance among all the statements.

Table 4:- Component Matrix.

\begin{tabular}{|c|c|c|c|c|c|}
\hline \multicolumn{6}{|l|}{ Component Matrix } \\
\hline & \multicolumn{5}{|c|}{ Component } \\
\hline & 1 & 2 & 3 & 4 & 5 \\
\hline $\begin{array}{l}\text { Feel dizziness and nausea due to fumes of chemicals used in } \\
\text { working period }\end{array}$ & .762 & & & & \\
\hline Suffer from allergies due to material used in work & .747 & & & & \\
\hline $\begin{array}{l}\text { Gets nose irritation sneezing and feel suffocated when dust } \\
\text { enters in nose }\end{array}$ & .747 & & & & \\
\hline Suffer from asthma due to occupation & .688 & & & & \\
\hline $\begin{array}{l}\text { I am not able to give sufficient time for cooking and feeding my } \\
\text { family }\end{array}$ & .682 & & & -.477 & \\
\hline I am not able to follow a regular meal pattern & .667 & & & -.492 & \\
\hline $\begin{array}{l}\text { Suffer from heavy palpitation of my heart while performing the } \\
\text { activity }\end{array}$ & .664 & & & & \\
\hline $\begin{array}{l}\text { Physically fatigued or exhausted while performing the activity } \\
\text { due to occupation }\end{array}$ & .543 & & & & \\
\hline
\end{tabular}




\begin{tabular}{|c|c|c|c|c|c|}
\hline Get injured due to stones sticks during working period & & .655 & & & \\
\hline I get less salary in comparison the quantum of my labour & & -.647 & .423 & & \\
\hline $\begin{array}{l}\text { Feel uncomfortable due to coarse and hard material of handles } \\
\text { of various }\end{array}$ & .417 & .622 & & & \\
\hline I have to do lot of work when compared to other workers & & -.619 & & & \\
\hline $\begin{array}{l}\text { Skin and nails remain hard and unsmooth during working } \\
\text { period }\end{array}$ & & & .627 & & \\
\hline I sweat or feel thirsty while working & & & .588 & & \\
\hline Feel irritation and redness is the eyes during working period & & & & .658 & \\
\hline Rainy season is not comfort able for occupation & & .454 & & & -.546 \\
\hline Summer season is not comfortable due to work & & .475 & & & -.506 \\
\hline \multicolumn{6}{|l|}{ Extraction Method: Principal Component Analysis. } \\
\hline
\end{tabular}

Above table shows the factor loading of the each question to the component, all the items were grouped in to five different components on the bases of highest factor loading with respect to the corresponding factors, where the issue of sign of the factor loading whether it is positive or negative, does not matter the factor loading corresponds to a particular factors which were greater than 0.4 for the present data.

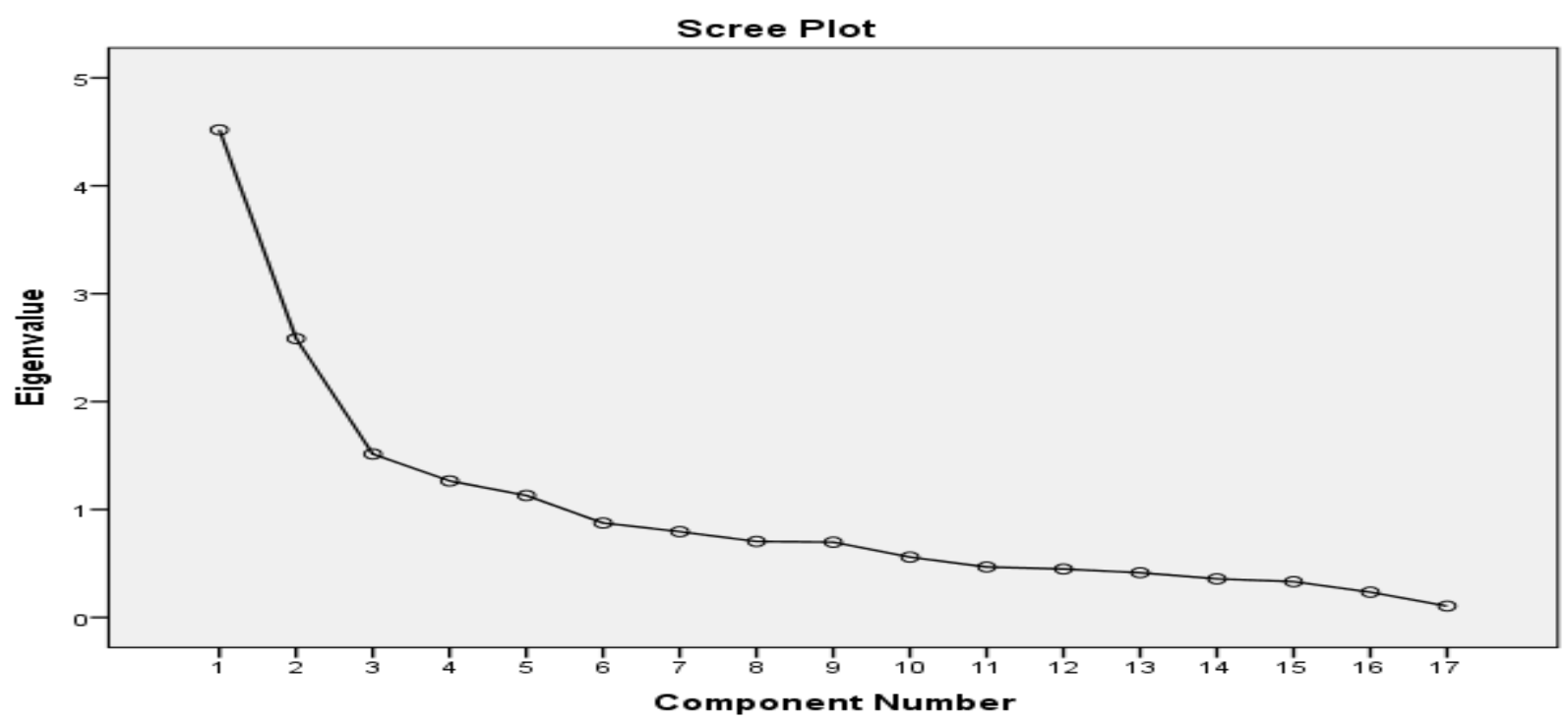

The screen plot shows that after five points the curve becomes flat that is, it is constant after certain number of points and these points are the number of extracted factors, that means the factors which have the Eigen value higher than1. From the table no. 4 it is evident five factors were extracted, with Eigen value greater than 1, which is supported by the screen plots as well.

Table 5:- Rotated Component Matrix.

\begin{tabular}{|c|c|c|c|c|c|c|}
\hline \multirow[t]{3}{*}{ S.N. } & \multicolumn{6}{|l|}{ Rotated Component Matrix } \\
\hline & & \multicolumn{5}{|c|}{ Component } \\
\hline & & 1 & 2 & 3 & 4 & 5 \\
\hline 1 & $\begin{array}{l}\text { Gets nose irritation sneezing and feel suffocated when } \\
\text { dust enters in nose }\end{array}$ & .802 & & & & \\
\hline 2 & Suffer from allergies due to material used in work & .782 & & & & \\
\hline 3 & Suffer from asthma due to occupation & .757 & & & & \\
\hline 4 & $\begin{array}{l}\text { Feel dizziness and nausea due to fumes of chemicals used } \\
\text { in working period }\end{array}$ & .748 & & & & \\
\hline 5 & $\begin{array}{l}\text { Suffer from heavy palpitation of my heart while } \\
\text { performing the activity }\end{array}$ & .617 & & & & \\
\hline 6 & Physically fatigued or exhausted while performing the & .512 & & & & \\
\hline
\end{tabular}




\begin{tabular}{|c|c|c|c|c|c|}
\hline & activity due to occupation & & & & \\
\hline 7 & I am not able to follow a regular meal pattern & .849 & & & \\
\hline 8 & $\begin{array}{l}\text { I am not able to give sufficient time for cooking and } \\
\text { feeding my family }\end{array}$ & .835 & & & \\
\hline 9 & I have to do lot of work when compared to other workers & .594 & .557 & & \\
\hline 10 & $\begin{array}{l}\text { Feel irritation and redness is the eyes during working } \\
\text { period }\end{array}$ & & .743 & & \\
\hline 11 & I get less salary in comparison the quantum of my labour & .471 & .635 & & \\
\hline 12 & Get injured due to stones sticks during working period & & -.586 & & \\
\hline 13 & $\begin{array}{l}\text { Feel uncomfortable due to coarse and hard material of } \\
\text { handles of various }\end{array}$ & & -.544 & & \\
\hline 14 & Rainy season is not comfort able for occupation & & & .862 & \\
\hline 15 & Summer season is not comfortable due to work & & & .853 & \\
\hline 16 & $\begin{array}{l}\text { Skin and nails remain hard and unsmooth during working } \\
\text { period }\end{array}$ & & & & .773 \\
\hline 17 & I sweat or feel thirsty while working & & & & .729 \\
\hline
\end{tabular}

The factor loading of each question to the component is similar to the component matrix, but the varimax rotation showed that there are no changes in the structure of factor loading, the output shows that, after rotation, changed in the factor loading were insignificant. Through factor analysis all the items were reduced into five different factors, which means if has to be considered. The physical stress has to be measured the level of stress of five different factors. The statements from one to six have the underlying information which is common among all the six and different from other four which are related to the physical discomfort in the body of the worker, therefore the first dimension is named as the physical exertion of the worker. The second dimension is explored by the $7,8,9^{\text {th }}$ statements which indicate the problems related to the family, therefore it is named as, lack of enough time for family. The third component were explained by the statements 10,11,12,13 showing the injuries of the past effecting the level of present stress, therefore it is named as prone to injuries, statement 14,15, were representing the workers stress due to the seasons, therefore it is named uncomfortable due to seasonal change. The statement 16, 17 were indicating about the permanent impact due to different working tools on different body parts, therefore it is named as, effect of working environment and tools. The responses related to the physical stress were analyzed and interpreted similarly.

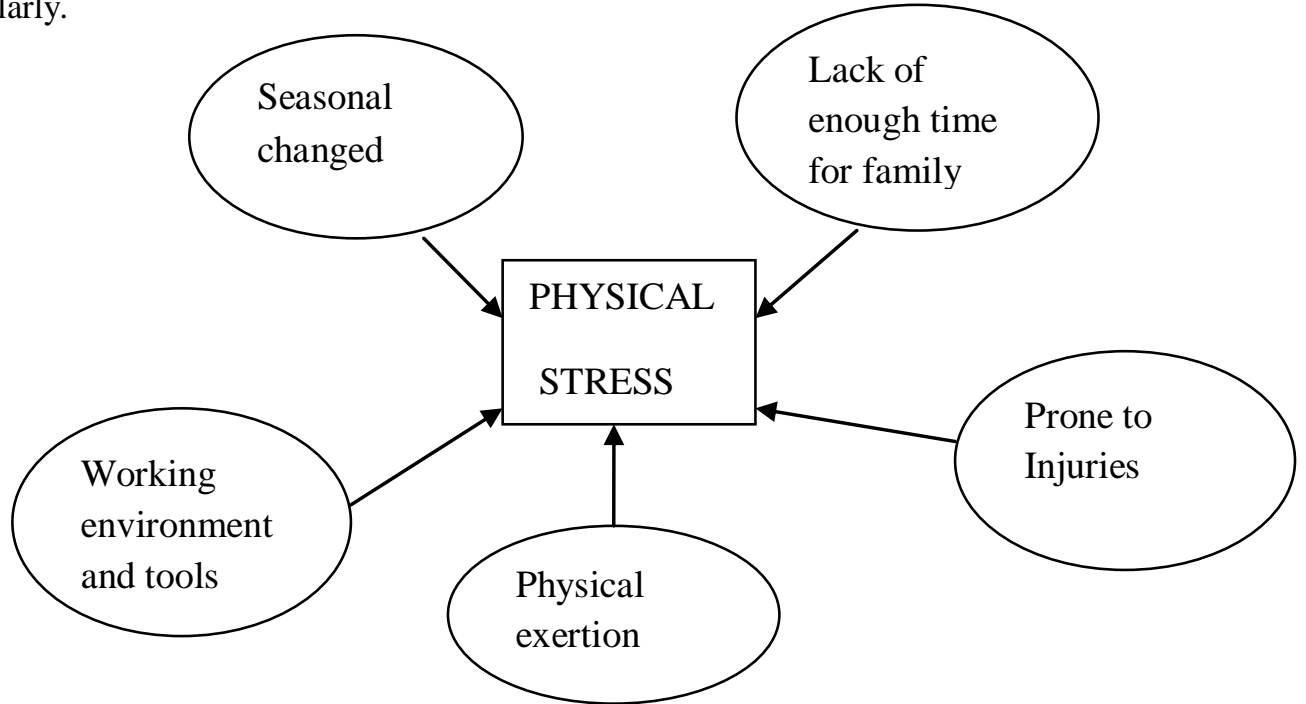

Fig 1:- Physical stress

From the results of the factor analysis, it may be concluded that the basic causes of the physical stress among the workers were due to five different factors, and they can be diagrammatically constructed through model as conceptualised at fig. No. 1 which gives the simple and clear cut representation of the whole model of the physical stress explained in the study. 


\section{Conclusion:-}

In the present global dynamic environment individuals have to face competitions everywhere, on the other hand the economy demands the enhanced productivity and the productivity is being enhanced through the exploitation of the resources and enhancing the motivational level, reducing the stress of the employee. In present environment, the working hours at the jobs have significantly increased. The workers have to work for long durations in awkward and static body postures, due to which the body parts of the workers are at high risk of musculoskeletal disorders. The changes in the working environment and conditions has lead to perceiving of stress by the workers, the stress perceived by the workers can be classified in to two parts occupational stress due to Job or work, and the physical stress as the tiredness and discomfort in the body parts of the workers. The present study identified five major sources of the physical stress among the workers of the unorganised sector, physical exertion, lack of enough time of family, prone to injuries, uncomfortable due to seasonal changes and working environments and tools. It can be concluded that the physical stress perceived by any of the workers basically arises from these five different factors. The employers may concentrate on these five factors and provide better working conditions to the employees. The stress levels of the employees may be regularly monitored and counseling sessions may be organized for them to enhance their physical and psychological well being and inform the productivity also will be increased, which is beneficial to the organization as well.

\section{References:-}

1. Devi K, and Kiran UV. Work life balance of women workers in construction industry. European academic research 2014; II (4): 4932-4946.

2. Devi K, and Kiran UV. Regression Modeling of Occupational Stress Among Workers of Unorganized Sector. International Journal of Science, Technology \& Society 2015; 1(2): 105-109.

3. Devi K, and Kiran UV. Occupational Stress Among Brick Kiln Workers Interaction of Demographic Variables. International Journal of Research in Social Sciences 2016; 6(2): 279-292.

4. Gaurav GD., Krushna GM., and Trivedi AA. Stress Among Unorganized Sector Workers in Vadodara City. International Journal of Research and Development of Health 2013; 1(4): 183-190.

5. Mohanraj P. and Manivannan L. Occupational Stress Among Migrated Workers In Unorganized Sectors. International Journal of Research in Management \& Technology (IJRMT) 2013; 3(1): 13-20.

6. NCEUS. Report on Conditions of Work and Promotion of Livelihoods in the Unorganized Sector. Academic Foundation2008; 1774.

7. Rajan D. Occupational Stress among Sanitary Workers: A Comparative Analysis. Int. Journal of Applied Sciences and Engineering Research 2014; 3(1): 39-62. Doi: 10.6088/ijaser.030100005.

8. Sparks K., Faragher B. and Cooper CL. Well- being and Occupational health in the $21^{\text {st }}$ Century Workplace. Journal of Occupational and Organizational Psychology 2001; 74: 489-509.

9. Srivastav AK. and Singh AP. Occupational Stress Index. Manovaigyanic Parikshan Sansthan Varanasi 1984.

10. Tiwary G., Gangopadhyay PK., Biswas S., Nayak K., Chakraborty D. and Halder LC. Psychosocial Stress of the Building Construction Workers. Human Biology Review 2013; 2(3): 207-222. URL: http://www.jstor.org/stable/4201133. 